\title{
TNBC vs. Non-TNBC: A Five-Year Retrospective Review of Differences in Mean Age, Family History, Smoking History and Stage at Diagnosis at an Inner City University Program
}

\author{
Khurram Tariq, ${ }^{\mathrm{a}, \mathrm{c}}$, Fauzia Rana ${ }^{\mathrm{b}}$
}

\begin{abstract}
Background: In recent years, breast cancer has been classified on the basis of estrogen or progesterone receptor (ER/PR) status and whether the human epidermal growth factor 2 receptor (HER2/ neu) protein is overexpressed. Based on this system, breast cancer is broadly divided into the triple negative breast cancer (TNBC) and the non-TNBC subtypes. TNBC is a subtype of breast cancer, notable for its propensity to metastasize early and display a comparatively more aggressive course than its non-TNBC counterpart. Certain clinico-pathologic and demographic risk factors have been associated with breast cancer. In this study, we aim to compare mean age, ethnicity, family history, tobacco use and stage at presentation between TNBC and non-TNBC subtypes at our inner city university program.
\end{abstract}

Methods: We reviewed data in our tumor registry between January 2000 and December 2005 with particular attention to mean age, race, family history, tobacco use and stage at presentation. We found a total of 445 patients with various subtypes of breast cancers. We included only those patients in whom the status of both $\mathrm{ER} / \mathrm{PR}$ and the status of Her2/neu protein overexpression were recorded. Our strict selection criteria lead to an exclusion of about 103 patients. Out of the remaining 342 patients, 39 were TNBC and 303 were non-TNBC.

Results: Mean age of onset for TNBC vs. non-TNBC patients was $59.87 \pm 15.67$ years vs. $60.09 \pm 13.98$ years respectively $(\mathrm{P}=$ 0.9272). In terms of ethnicity, TNBC vs. non-TNBC patients had the following racial backgrounds: black, $58.97 \%$ vs. $39.27 \%$; white, $35.90 \%$ vs. $57.76 \%$; Chinese, $2.56 \%$ vs. $0.99 \%$; others, $2.57 \%$ vs.

Manuscript accepted for publication December 13, 2013

${ }^{a}$ Department of Internal Medicine, College of Medicine, University of Florida, Jacksonville, FL 32209, USA

${ }^{\mathrm{b}}$ Division of Hematology \& Medical Oncology, College of Medicine, University of Florida, Jacksonville, FL 32209, USA

${ }^{\mathrm{c} C o r r e s p o n d i n g ~ a u t h o r: ~ K h u r r a m ~ B i l a l ~ T a r i q, ~ D e p a r t m e n t ~ o f ~ I n t e r n a l ~}$ Medicine, College of Medicine, University of Florida, 653 West 8th Street, Box L 18, Jacksonville, FL 32209, USA.

Email: Khurram.Tariq@jax.ufl.edu

doi: http://dx.doi.org/10.4021/wjon738w
$1.98 \%$ respectively $(\mathrm{P}=0.004, \mathrm{OR}=2.755)$. Comparisons with respect to a history of tobacco abuse for TNBC vs. non-TNBC patients revealed a positive smoking history in $20.51 \%$ vs. $27.72 \%$ whereas there was no former or current smoking history in $71.79 \%$ vs. $61.72 \%$ respectively $(\mathrm{P}=0.4385)$. Comparison of family history of a breast cancer in TNBC vs. non-TNBC patients showed that positive family history of breast cancer was seen in $30.77 \%$ vs. $33.33 \%$, no family history of cancer was seen in $51.28 \%$ vs. $51.82 \%$ and unknown $17.95 \%$ vs. $14.85 \%(\mathrm{P}=0.8384)$. Pathologic stage at the time of diagnosis for TNBC vs. non-TNBC patients was as follows: stage $0,15.79 \%$ vs. $11.37 \%(\mathrm{P}=0.4332)$; stage 1 , $34.21 \%$ vs. $30.98 \%(\mathrm{P}=0.6890)$; stage $2,28.98 \%$ vs. $37.25 \%(\mathrm{P}$ $=0.3205)$; stage $3,18.42 \%$ vs. $17.25 \%(\mathrm{P}=0.0 .8591)$; and stage $4,3.63 \%$ vs. $3.14 \%(\mathrm{P}=0.8651)$. Analysis using Chi-square test revealed $\chi^{2}$ value of 0.855 .

Conclusion: Our results add to the growing body of evidence pertaining to the association of certain demographic and clinicopathologic characteristics in women with breast cancer. We found that in our patient population, there is a significant ethnic predisposition for the two types of breast cancers that we studied. African Americans were more likely to have TNBC compared to the higher frequency of non-TNBC in white females. We did not find a significant difference in mean age, cigarette smoking, family history and stage at diagnosis between the TNBC and non-TNBC breast cancer patients. These findings are all consistent with the previously published research studies.

Keywords: TNBC; Non-TNBC; Breast cancer; Demographical differences

\section{Introduction}

Breast cancer in one of the most common form of cancer among women and by some accounts it represents about a quarter of the 1.1 million newly diagnosed female malignancies each year $[1,2]$. Breast cancer is also the leading cause of cancer-related deaths throughout the world with case fatality rates being highest in the developing countries [3]. Despite the increased educational and monetary investments by various public and private sector interest groups to improve outcomes, breast cancer still remains the second most sig- 
Table 1. Comparison of Demographics and Clinico-pathologic Characteristics in TNBC and Non-TNBC Patients

\begin{tabular}{|c|c|c|c|}
\hline Possible risk factors & TNBC (\%) & Non-TNBC (\%) & \\
\hline Mean age (years) & $59.87 \pm 15.67$ & $60.09 \pm 13.98$ & $\mathrm{P}=0.9272$ \\
\hline Ethnicity & & & $\mathrm{P}=0.004 ; \mathrm{OR}=2.755$ \\
\hline Black & 58.97 & 39.27 & \\
\hline White & 35.90 & 57.76 & \\
\hline Chinese & 2.56 & 0.99 & \\
\hline Others & 2.57 & 1.98 & \\
\hline \multicolumn{4}{|c|}{ Smoking history (past or present) } \\
\hline Yes & 20.51 & 27.72 & $\mathrm{P}=0.4385$ \\
\hline No & 71.79 & 61.72 & \\
\hline \multicolumn{4}{|l|}{ Family history } \\
\hline Yes & 30.77 & 33.33 & $\mathrm{P}=0.8384$ \\
\hline No & 51.28 & 51.82 & \\
\hline Unknown & 17.69 & 14.85 & \\
\hline \multicolumn{4}{|l|}{ Stage at diagnosis } \\
\hline Stage 0 & 15.79 & 11.37 & $\mathrm{P}=0.4332$ \\
\hline Stage 1 & 34.21 & 30.98 & $\mathrm{P}=0.6890$ \\
\hline Stage 2 & 28.98 & 37.25 & $\mathrm{P}=0.3205$ \\
\hline Stage 3 & 18.42 & 17.25 & $\mathrm{P}=0.8591$ \\
\hline Stage 4 & 3.63 & 3.14 & $\mathrm{P}=0.8651$ \\
\hline Chi-square test $\left(\chi^{2}\right)$ & & 0.855 & \\
\hline
\end{tabular}

nificant cause of cancer-related mortality in the US population [4]. Per the 2002 guidelines by the National Cancer Control Program set forth by the World Health Organization, early screening, detection along with adequate therapy has been singled out as the most important factors in the fight for reduction in breast cancer mortality [5]. This is the basis of our 5-year retrospect cohort study. We looked at a variety of clinico-pathologic and demographic characteristics between the triple negative breast cancer (TNBC) and non-TNBC subtypes at our inner city program to compare our findings with some of the research studies published elsewhere.

\section{Methods}

We reviewed data in our tumor registry between January 2000 and December 2005 with particular attention to mean age, race, family history, tobacco use and stage at presentation. We found a total of 445 patients with various subtypes of breast cancers. We included only those patients in whom the status of both estrogen and progesterone receptors (ER/ PR) and the status of human epidermal growth factor 2 receptor (Her2/neu) protein overexpression were recorded. Our strict selection criteria lead to an exclusion of about 103 patients. Out of the remaining 342 patients, 39 were TNBC and 303 were non-TNBC.

\section{Results}

Mean age of onset for TNBC vs. non-TNBC patients was $59.87 \pm 15.67$ years vs. $60.09 \pm 13.98$ years respectively ( $\mathrm{P}$ $=0.9272$ ). In terms of ethnicity, TNBC vs. non-TNBC patients had the following racial backgrounds: black, 58.97\% vs. $39.27 \%$; white, $35.90 \%$ vs. $57.76 \%$; Chinese, $2.56 \%$ vs. $0.99 \%$; others, $2.57 \%$ vs. $1.98 \%$ respectively $(\mathrm{P}=0.004$, OR $=2.755$ ). Comparisons with respect to a history of tobacco abuse for TNBC vs. non-TNBC patients revealed a positive smoking history in $20.51 \%$ vs. $27.72 \%$ whereas there was no former or current smoking history in $71.79 \%$ vs. $61.72 \%$ 
respectively $(\mathrm{P}=0.4385)$. Comparison of family history of a breast cancer in TNBC vs. non-TNBC patients showed that positive family history of breast cancer was seen in $30.77 \%$ vs. $33.33 \%$, no family history of cancer was seen in $51.28 \%$ vs. $51.82 \%$ and unknown $17.95 \%$ vs. $14.85 \%(\mathrm{P}=0.8384)$. Pathologic stage at the time of diagnosis for TNBC vs. nonTNBC patients was as follows: stage $0,15.79 \%$ vs. $11.37 \%$ $(\mathrm{P}=0.4332)$; stage $1,34.21 \%$ vs. $30.98 \%(\mathrm{P}=0.6890)$; stage 2 , $28.98 \%$ vs. $37.25 \%(\mathrm{P}=0.3205)$; stage $3,18.42 \%$ vs. $17.25 \%(\mathrm{P}=0.0 .8591)$; and stage $4,3.63 \%$ vs. $3.14 \%(\mathrm{P}=$ $0.8651)$. Analysis using Chi-square test revealed $\chi^{2}$ value of 0.855 . These findings are summarized in Table 1 .

\section{Discussion}

World Health Organization classifies breast cancer on the basis of histopathologic characteristics [6]. While this method successfully delineates breast cancer into several invasive subtypes, it fails to predict prognosis and treatment possibilities [7]. Recent advancements in the techniques used for immuno-histochemical and gene expression studies have lead to a distinct subdivision of breast cancer on the basis of protein expression and molecular subtypes respectively [8-11]. These newer techniques have resulted in the appreciation of breast cancer on the basis of expression for HER2/neu proteins and ER and PR [12]. Breast cancer classification, on the basis of receptors and proteins, has lead to the recognition of TNBC. It is classified as a type of breast cancer that lacks expression for ER and PR and does not over express Her2/ neu proteins [13-15].

Due to its unique pathologic and clinical features, ranging from younger age at onset, higher propensity for distant visceral metastasis, poor outcomes and a more aggressive overall presentation, TNBC or tumor negative breast cancer has recently become the focal of intense breast cancer research [16]. TNBC subtype generally carries a worse prognosis when compared to its non-TNBC counterparts; however, it responds very well to the neo-adjuvant and adjuvant chemotherapies and conversely carries a much favorable response with these therapies [17]. TNBC has a higher predilection for certain ethnicities which is why its incidence has ranged from $11.2 \%$ in studies with a predominantly white patient population to as high as 39\% in studies with a larger proportion of African American patients [18, 19]. In the Western world, the general consensus among the oncology community at large puts the prevalence of TNBC at around $15-20 \%[20,21]$. Based on our research, the prevalence of TNBC at our institution is $12.87 \%$. While this percentage is lower than the generally agreed upon frequency of " 15 $20 \%$, we can attribute our lower prevalence to the diverse demographics in our sample population.

Irrespective of the breast cancer subtypes, the median age of patients at the time of affliction is also considered an important prognostic factor [22]. There are certain differences between the age of onset and the various breast cancer subtypes. TNBCs tend to occur at an earlier age compared to the more advances age of onset seen in the non-TNBC [23]. Since TNBC subtype has only recently been recognized as a distinct entity, it is not well understood if the prognosis differs between patients who developed TNBC at a younger age compared to those women who developed it at an older age [23]. Similarly the research data available are not conclusive enough to make a convincing argument for or against a biologic or clinical difference in TNBC patients by age at diagnosis [23]. The sparse research data available on breast cancer in general have shown variable results with some making a strong case for age as a distinct prognostic factor for breast cancer in younger patients whereas others failing to support this relationship [24, 25]. Our research study adds further statistical analysis to this growing body of evidence. We found that at our inner city university program, there was no difference in mean age at the time of diagnosis $(\mathrm{P}=$ 0.9272 ) between TNBC and non-TNBC patients.

Breast cancer subtypes also have a strong predilection with certain ethnic backgrounds. Data pooled from several research studies have indicated that African American women are more likely to have TNBC subtype than white women [26-31]. At our inner city institute, we found a significant statistical difference between the various ethnicities and their relationship with the two breast cancer subtypes $(\mathrm{P}=0.004)$. Our retrospect research study indicated that black women were more likely to have TNBC, whereas the non-TNBC was more prevalent in white women.

Several in vivo and in vitro studies have shown that cigarette smoking has carcinogenic properties and the breast cancer tissue is a potential target for these carcinogens [32]. While the mechanism of action is not entirely understood, it is believed that the carcinogens in cigarette smoke are transported by the plasma lipoproteins on their journey from the alveoli to the breast tissue [33, 34]. Because of cigarette smoke's strong affinity for these lipoproteins, it is more likely to be stored in adipocytes in the breast tissue which can later be activated by the human mammary epithelial cells to unleash its carcinogenic effect [35]. In cigarette smokers, the number of cigarette smoke based DNA adducts are significantly higher than in non-smokers [36-38]. Furthermore, researchers also point to the higher accumulation of P53 gene mutations in breast cancer tumors of smokers compared with non-smokers, which is also comparable to the mutational spectrum seen in lung cancer patients [32]. Besides the aforementioned biologic explanations, cigarette smoke is also thought to have an anti-estrogenic effect, supported by the observation that cigarette smokers have a lower bone density, an earlier age at menopause, decreased urinary levels of estrogens and an attenuated response to the hormone replacement therapy compared to non-smokers [39-42]. Ironically, the same cigarette smoke which is considered a 
risk factor for breast cancer can also have a protective role against breast cancer due to its anti-estrogenic effect [43]. With both a detrimental as well as a beneficiary profile, it is not difficult to imagine why several research studies, published previously, have shown inconsistent results about the relationship between cigarette smoking and breast cancer [44]. More recent research studies, however, have suggested a strong correlation between breast cancer in long-term cigarettes smokers and those who smoked before the birth of their first child [45-49]. In our research, there was no significant association between smoking status and cancer subtypes $(\mathrm{P}=0.4385)$ which is in agreement with some of the earlier studies mentioned above.

In our research study, we also looked into family history and its relationship with TNBC and non-TNBC patients. About $10 \%$ of women with breast cancer have a positive family history of breast cancer [50]. A positive family history of breast cancer in a first-degree relative increases the risk of breast cancer by as much as two folds [50-52]. Both breast and ovarian cancers in the first-degree relatives are considered an established risk factor for the development of breast cancer [51]. Besides the prognostic significance, a positive family history is also associated with improved compliance with the early detection strategies like the mammography screenings [53-56]. Women with a positive family history are more likely to have fewer false beliefs about breast cancer and are likely to receive early breast cancer screenings and comprehensive breast cancer treatment [57, 58]. This might explain why, at our inner city program, we had a higher prevalence of breast cancer patients with a positive cancer history. Published studies have noted higher breast cancer mortality in women who have lower participation rates in mammography screening programs [59]. This further underscores the significance and future implications for patients who have a family history significant for another relative with breast cancer. At out inner city program, we found that there was no significant association between a positive family history of cancer in TNBC and non-TNBC subtypes ( $\mathrm{P}=$ 0.8384 ). It is important to note that a positive family history of breast cancer does not impact all-cause mortality and a review of several published studies have failed to conclusively establish this relationship [53, 60-67]. Furthermore, BRCA-1 and BRCA-2 germ line mutations account for only a quarter of the total breast cancer cases and a significant portion of women with breast cancer acquire the affliction in the absence of this familial link [68].

Besides all the aforementioned risk factors, stage at diagnosis likely plays the most significant role in breast cancer mortality. Published research data by the National Cancer Institute have shown that the 5-year survival rate among women diagnosed with breast cancer at stage 1 is as high as $88 \%$ compared with the dismally low survival rate of around $15 \%$ for patients diagnosed with breast cancer at stage 4 [69, 70]. Non-Hispanic whites and Asians are more likely to be diagnosed at an earlier stage compared to Hispanic and black women who are likely to be diagnosed at an advanced stage $[69,70]$. In our retrospect cohort research study, when accounting for stage at the time of diagnosis, TNBC was as prevalent as non-TNBC at all stages with $P$ values of 0.4332 , $0.6890,0.3205,0.8591$ and 0.8651 for stage $0,1,2,3$ and 4 respectively. We found no significant difference in the stage at diagnosis in TNBC compared with the non-TNBC patients in our patient population.

\section{Conclusions}

Our findings further contribute to the growing body of evidence pertaining to the association of certain demographic and clinico-pathologic characteristics in women with TNBC and non- TNBC. We found that in our patient population, there is a significant ethnic predisposition for these two subtypes of breast cancers. African Americans were more likely to have TNBC compared to the higher frequency of non-TN$\mathrm{BC}$ in white females. We did not find a significant difference in mean age, cigarette smoking, family history and stage at diagnosis between the TNBC and non-TNBC patients. These findings are all consistent with the previously published research studies.

\section{Grant Support}

None.

\section{Financial Disclosures}

No financial help was taken from any internal or external source. This being a retrospect study, no financial support was required.

\section{Conflict of Interest}

The authors declare that there is no conflict of interests regarding the publication of this article.

\section{References}

1. Parkin DM, Fernandez LM. Use of statistics to assess the global burden of breast cancer. Breast J. 2006;12(Suppl 1):S70-80.

2. Parkin DM, Bray F, Ferlay J, Pisani P. Global cancer statistics, 2002. CA Cancer J Clin. 2005;55(2):74-108.

3. Anderson BO, Yip CH, Smith RA, Shyyan R, Sener SF, Eniu A, Carlson RW, et al. Guideline implementation for breast healthcare in low-income and middle-income 
countries: overview of the Breast Health Global Initiative Global Summit 2007. Cancer. 2008;113(8 Suppl):2221-2243.

4. Siegel R, Ward E, Brawley O, Jemal A. Cancer statistics, 2011: the impact of eliminating socioeconomic and racial disparities on premature cancer deaths. CA Cancer J Clin. 2011;61(4):212-236.

5. National Cancer Control Programs. Policies and managerial 5.guidelines, 2nd. ed. Geneva, World Health Organization, 2002.

6. Tavassoli FA, Devilee P. World health organization of tumors. Pathology and genetics of tumors of the breast and female genital organs. Lyon, IARC press. 2003.

7. de Ruijter TC, Veeck J, de Hoon JP, van Engeland M, Tjan-Heijnen VC. Characteristics of triple-negative breast cancer. J Cancer Res Clin Oncol. 2011;137(2):183192.

8. Perou CM, Sorlie T, Eisen MB, van de Rijn M, Jeffrey SS, Rees CA, Pollack JR, et al. Molecular portraits of human breast tumours. Nature. 2000;406(6797):747752.

9. Sorlie T, Perou CM, Tibshirani R, Aas T, Geisler S, Johnsen H, Hastie T, et al. Gene expression patterns of breast carcinomas distinguish tumor subclasses with clinical implications. Proc Natl Acad Sci U S A. 2001;98(19):10869-10874.

10. Callagy G, Cattaneo E, Daigo Y, Happerfield L, Bobrow LG, Pharoah PD, Caldas C. Molecular classification of breast carcinomas using tissue microarrays. Diagn Mol Pathol. 2003;12(1):27-34.

11. Abd El-Rehim DM, Ball G, Pinder SE, Rakha E, Paish C, Robertson JF, Macmillan D, et al. High-throughput protein expression analysis using tissue microarray technology of a large well-characterised series identifies biologically distinct classes of breast cancer confirming recent cDNA expression analyses. Int J Cancer. 2005;116(3):340-350.

12. Ismail-Khan R, Bui MM. A review of triple-negative breast cancer. Cancer Control. 2010;17(3):173-176.

13. van 't Veer LJ, Dai H, van de Vijver MJ, He YD, Hart AA, Mao M, Peterse HL, et al. Gene expression profiling predicts clinical outcome of breast cancer. Nature. 2002;415(6871):530-536.

14. Sorlie T, Tibshirani R, Parker J, Hastie T, Marron JS, Nobel A, Deng S, et al. Repeated observation of breast tumor subtypes in independent gene expression data sets. Proc Natl Acad Sci U S A. 2003;100(14):84188423.

15. Paik S, Tang G, Shak S, Kim C, Baker J, Kim W, Cronin $\mathrm{M}$, et al. Gene expression and benefit of chemotherapy in women with node-negative, estrogen receptor-positive breast cancer. J Clin Oncol. 2006;24(23):3726-3734.

16. Anders C, Carey LA. Understanding and treating triple-negative breast cancer. Oncology (Williston Park).
2008;22(11):1233-1239; discussion 1239-1240, 1243.

17. Liedtke C, Mazouni C, Hess KR, Andre F, Tordai A, Mejia JA, Symmans WF, et al. Response to neoadjuvant therapy and long-term survival in patients with triplenegative breast cancer. J Clin Oncol. 2008;26(8):12751281.

18. Carey LA, Perou CM, Livasy CA, Dressler LG, Cowan D, Conway K, Karaca G, et al. Race, breast cancer subtypes, and survival in the Carolina Breast Cancer Study. JAMA. 2006;295(21):2492-2502.

19. Dent R, Trudeau M, Pritchard KI, Hanna WM, Kahn HK, Sawka CA, Lickley LA, et al. Triple-negative breast cancer: clinical features and patterns of recurrence. Clin Cancer Res. 2007;13(15 Pt 1):4429-4434.

20. Silver DP, Richardson AL, Eklund AC, Wang ZC, Szallasi Z, Li Q, Juul N, et al. Efficacy of neoadjuvant Cisplatin in triple-negative breast cancer. J Clin Oncol. 2010;28(7):1145-1153.

21. Kaplan HG, Malmgren JA, Atwood MK. Impact of triple negative phenotype on breast cancer prognosis. Poster presented at: 29th Annual San Antonio Breast Cancer Symposium; December 14-17, San Antonio, TX, 2006.

22. Aleskandarany MA, Green AR, Benhasouna AA, Barros FF, Neal K, Reis-Filho JS, Ellis IO, et al. Prognostic value of proliferation assay in the luminal, HER2-positive, and triple-negative biologic classes of breast cancer. Breast Cancer Res. 2012;14(1):R3.

23. Fredholm H, Eaker S, Frisell J, Holmberg L, Fredriksson I, Lindman H. Breast cancer in young women: poor survival despite intensive treatment. PLoS One. 2009;4(11):e7695.

24. Azim HA, Jr., Michiels S, Bedard PL, Singhal SK, Criscitiello C, Ignatiadis M, Haibe-Kains B, et al. Elucidating prognosis and biology of breast cancer arising in young women using gene expression profiling. Clin Cancer Res. 2012;18(5):1341-1351.

25. Kim EK, Noh WC, Han W, Noh DY. Prognostic significance of young age ( $<35$ years) by subtype based on ER, PR, and HER2 status in breast cancer: a nationwide registry-based study. World J Surg. 2011;35(6):1244-1253.

26. Menashe I, Anderson WF, Jatoi I, Rosenberg PS. Underlying causes of the black-white racial disparity in breast cancer mortality: a population-based analysis. J Natl Cancer Inst. 2009;101(14):993-1000.

27. Dignam JJ. Efficacy of systemic adjuvant therapy for breast cancer in African-American and Caucasian women. J Natl Cancer Inst Monogr. 2001;(30):36-43.

28. Ayanian JZ, Kohler BA, Abe T, Epstein AM. The relation between health insurance coverage and clinical outcomes among women with breast cancer. N Engl J Med. 1993;329(5):326-331.

29. Bradley CJ, Given CW, Roberts C. Race, socioeconomic status, and breast cancer treatment and survival. J Natl Cancer Inst. 2002;94(7):490-496. 
30. Jatoi I, Becher H, Leake CR. Widening disparity in survival between white and African-American patients with breast carcinoma treated in the U. S. Department of Defense Healthcare system. Cancer. 2003;98(5):894-899.

31. McPherson K, Steel CM, Dixon JM. ABC of breast diseases. Breast cancer-epidemiology, risk factors, and genetics. BMJ. 2000;321(7261):624-628.

32. Conway K, Edmiston SN, Cui L, Drouin SS, Pang J, He $\mathrm{M}$, Tse CK, et al. Prevalence and spectrum of p53 mutations associated with smoking in breast cancer. Cancer Res. 2002;62(7):1987-1995.

33. Yamasaki E, Ames BN. Concentration of mutagens from urine by absorption with the nonpolar resin XAD-2: cigarette smokers have mutagenic urine. Proc Natl Acad Sci U S A. 1977;74(8):3555-3559.

34. Shu HP, Bymun EN. Systemic excretion of benzo(a)pyrene in the control and microsomally induced rat: the influence of plasma lipoproteins and albumin as carrier molecules. Cancer Res. 1983;43(2):485-490.

35. MacNicoll AD, Easty GC, Neville AM, Grover PL, Sims P. Metabolism and activation of carcinogenic polycyclic hydrocarbons by human mammary cells. Biochem Biophys Res Commun. 1980;95(4):1599-1606.

36. Faraglia B, Chen SY, Gammon MD, Zhang Y, Teitelbaum SL, Neugut AI, Ahsan H, et al. Evaluation of 4-aminobiphenyl-DNA adducts in human breast cancer: the influence of tobacco smoke. Carcinogenesis. 2003;24(4):719-725.

37. Firozi PF, Bondy ML, Sahin AA, Chang P, Lukmanji F, Singletary ES, Hassan MM, et al. Aromatic DNA adducts and polymorphisms of CYP1A1, NAT2, and GSTM1 in breast cancer. Carcinogenesis. 2002;23(2):301-306.

38. Perera FP, Estabrook A, Hewer A, Channing K, Rundle A, Mooney LA, Whyatt R, et al. Carcinogen-DNA adducts in human breast tissue. Cancer Epidemiol Biomarkers Prev. 1995;4(3):233-238.

39. Jensen J, Christiansen C, Rodbro P. Cigarette smoking, serum estrogens, and bone loss during hormone-replacement therapy early after menopause. $\mathrm{N}$ Engl J Med. 1985;313(16):973-975.

40. Jensen J, Christiansen C. Effects of smoking on serum lipoproteins and bone mineral content during postmenopausal hormone replacement therapy. Am J Obstet Gynecol. 1988;159(4):820-825.

41. Baron JA, La Vecchia C, Levi F. The antiestrogenic effect of cigarette smoking in women. Am J Obstet Gynecol. 1990;162(2):502-514.

42. MacMahon B, Trichopoulos D, Cole P, Brown J. Cigarette smoking and urinary estrogens. $\mathrm{N}$ Engl J Med. 1982;307(17):1062-1065.

43. Clemons M, Goss P. Estrogen and the risk of breast cancer. N Engl J Med. 2001;344(4):276-285.

44. Terry PD, Rohan TE. Cigarette smoking and the risk of breast cancer in women: a review of the literature. Can- cer Epidemiol Biomarkers Prev. 2002;11(10 Pt 1):953971.

45. Terry PD, Miller AB, Rohan TE. Cigarette smoking and breast cancer risk: a long latency period? Int J Cancer. 2002;100(6):723-728.

46. Olson JE, Vachon CM, Vierkant RA, Sweeney C, Limburg PJ, Cerhan JR, Sellers TA. Prepregnancy exposure to cigarette smoking and subsequent risk of postmenopausal breast cancer. Mayo Clin Proc. 2005;80(11):14231428.

47. Li CI, Malone KE, Daling JR. The relationship between various measures of cigarette smoking and risk of breast cancer among older women 65-79 years of age (United States). Cancer Causes Control. 2005;16(8):975-985.

48. Band PR, Le ND, Fang R, Deschamps M. Carcinogenic and endocrine disrupting effects of cigarette smoke and risk of breast cancer. Lancet. 2002;360(9339):10441049.

49. Gram IT, Braaten T, Terry PD, Sasco AJ, Adami HO, Lund E, Weiderpass E. Breast cancer risk among women who start smoking as teenagers. Cancer Epidemiol Biomarkers Prev. 2005;14(1):61-66.

50. Familial breast cancer: collaborative reanalysis of individual data from 52 epidemiological studies including 58,209 women with breast cancer and 101,986 women without the disease. Lancet. 2001;358(9291):13891399.

51. Pharoah PD, Day NE, Duffy S, Easton DF, Ponder BA. Family history and the risk of breast cancer: a systematic review and meta-analysis. Int J Cancer. 1997;71(5):800809.

52. Lux MP, Fasching PA, Beckmann MW. Hereditary breast and ovarian cancer: review and future perspectives. J Mol Med (Berl). 2006;84(1):16-28.

53. Figueiredo JC, Ennis M, Knight JA, McLaughlin JR, Hood N, O’Malley F, Andrulis IL, et al. Influence of young age at diagnosis and family history of breast or ovarian cancer on breast cancer outcomes in a population-based cohort study. Breast Cancer Res Treat. 2007;105(1):69-80.

54. Margolin S, Johansson H, Rutqvist LE, Lindblom A, Fornander T. Family history, and impact on clinical presentation and prognosis, in a population-based breast cancer cohort from the Stockholm County. Fam Cancer. 2006;5(4):309-321.

55. McCaul KD, Branstetter AD, Schroeder DM, Glasgow RE. What is the relationship between breast cancer risk and mammography screening? A meta-analytic review. Health Psychol. 1996;15(6):423-429.

56. Cohen M. Breast cancer early detection, health beliefs, and cancer worries in randomly selected women with and without a family history of breast cancer. Psychooncology. 2006;15(10):873-883.

57. Gansler T, Henley SJ, Stein K, Nehl EJ, Smigal C, 
Slaughter E. Sociodemographic determinants of cancer treatment health literacy. Cancer. 2005;104(3):653-660.

58. Verkooijen HM, Chappuis PO, Rapiti E, Vlastos G, Fioretta G, Sarp S, Sappino AP, et al. Impact of familial risk factors on management and survival of early-onset breast cancer: a population-based study. $\mathrm{Br} \mathrm{J}$ Cancer. 2006;94(2):231-238.

59. Bouchardy C, Verkooijen HM, Fioretta G. Social class is an important and independent prognostic factor of breast cancer mortality. Int J Cancer. 2006;119(5):1145-1151.

60. Eerola H, Vahteristo P, Sarantaus L, Kyyronen P, Pyrhonen S, Blomqvist C, Pukkala E, et al. Survival of breast cancer patients in BRCA1, BRCA2, and non-BRCA1/2 breast cancer families: a relative survival analysis from Finland. Int J Cancer. 2001;93(3):368-372.

61. Russo A, Herd-Smith A, Gestri D, Bianchi S, Vezzosi V, Rosselli Del Turco M, Cardona G. Does family history influence survival in breast cancer cases? Int J Cancer. 2002;99(3):427-430

62. Verhoog LC, Brekelmans CT, Seynaeve C, Dahmen G, van Geel AN, Bartels CC, Tilanus-Linthorst MM, et al. Survival in hereditary breast cancer associated with germline mutations of BRCA2. J Clin Oncol. 1999;17(11):3396-3402.

63. Jobsen JJ, Meerwaldt JH, van der Palen J. Family history in breast cancer is not a prognostic factor? Breast. 2000;9(2):83-87.

64. Vlastos G, Mirza NQ, Meric F, Hunt KK, Mirza AN,
Newman LA, Ames FC, et al. Breast-conservation therapy in early-stage breast cancer patients with a positive family history. Ann Surg Oncol. 2002;9(9):912-919.

65. Veronesi A, de Giacomi C, Magri MD, Lombardi D, Zanetti M, Scuderi C, Dolcetti R, et al. Familial breast cancer: characteristics and outcome of BRCA 1-2 positive and negative cases. BMC Cancer. 2005;5:70.

66. Brekelmans CT, Tilanus-Linthorst MM, Seynaeve C, vd Ouweland A, Menke-Pluymers MB, Bartels CC, Kriege $\mathrm{M}$, et al. Tumour characteristics, survival and prognostic factors of hereditary breast cancer from BRCA2-, BRCA1- and non-BRCA1/2 families as compared to sporadic breast cancer cases. Eur J Cancer. 2007;43(5):867-876.

67. Rennert G, Bisland-Naggan S, Barnett-Griness O, BarJoseph N, Zhang S, Rennert HS, Narod SA. Clinical outcomes of breast cancer in carriers of BRCA1 and BRCA2 mutations. N Engl J Med. 2007;357(2):115123.

68. Chappuis PO, Rosenblatt J, Foulkes WD. The influence of familial and hereditary factors on the prognosis of breast cancer. Ann Oncol. 1999;10(10):1163-1170.

69. National Cancer Institute, Surveillance Research Program. Fast Stats: An interactive tool for access to SEER cancer statistics. 2011.

70. Li CI, Malone KE, Daling JR. Differences in breast cancer stage, treatment, and survival by race and ethnicity. Arch Intern Med. 2003;163(1):49-56. 